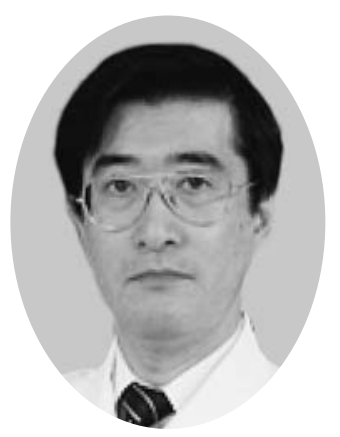

\title{
付属病院臨床研修センターの 設置とその役割
}

\section{横田裕行}

日本医科大学付属病院臨床研修センター長

大学院医学研究科/医学部 教授 (侵襲生体管理学)

平成 21 年 4 月, 付属病院に臨床研修センターが新たに設置されたことに伴い, 私は初代の臨床研修センター長 を拝命いたしました．私は付属病院臨床研修センターの役割には三つの大きな柱があると考えています。一つ目は 大学病院の財産であり, 将来的に本学, そして日本の医療を支える優秀な医師となるべき初期研修医や専修医の採 用や教育に積極的に関与することです。二つ目は付属病院に勤務するすべての職種, 例えば看護部, 薬剤部, 事務 部に対して医療人としての教育, 三つ目が付属病院に勤務する医師への生涯教育です.

これらの柱の中で最優先課題として考え活動したのが，初期研修医，専修医に対する対応です．新しい臨床研修 医制度が構築されて以来 6 年が経過しますが, 毎年少しずつ変更があります．大学の付属病院としても，それらの 変更に柔軟に対応し, 将来を先取りした魅力ある研修プログラムを提示することが, 優秀な研修医を確保する上で も極めて重要と考えたからです. 付属病院臨床研修センターは大学の卒後研修委員会 (委員長, 飯野靖彦教授), および付属 3 病院の研修管理委員会と密接に連絡を取り合い, この一年間積極的に活動してきました. 初期研修医 採用に対しては付属病院, 武蔵小杉病院, 多摩永山病院と共通のカリキュラムを作成し, 従来からの研修協力病院 群に加え, 武蔵野赤十字病院や総合会津中央病院, 神栖済生会病院, あるいは足利赤十字病院など初期研修医に人 気があり，しかも特徵ある総合病院に協力病院（協力施設）として加わっていただきました. その結果, 臨床研修 指定病院の中で最も魅力のあるプログラムを提示することができ, 平成 22 年度の初期研修医の応募状況は前年を 大きく上回ることになりました. また, 平成 21 年 12 月に特定非営利活動法人 卒後臨床研修評価機構から全国の 大学付属病院としては 4 施設目となる認定を頂きました (図参照). 今後は千葉北総病院を含め付属 4 病院や特徵 のある協力病院とさらに連携を強め，より魅力のある教育プログラムを作成していこうと考えています。

また, 残りの 2 つ柱, すなわち医師だけでなく, 付属病院に勤務するすべての職種を対象とした医療人として の生涯教育に関しても, 様々なアイデアを出しながら進めていきたいと思っています。具体的には留学帰国後や大 学院修了後の医師, 出産後の女性医師が勤務医として安心して職場に復帰できるような生涯教育システムを構築す ることも大きな使命であると考え, カリキュラムを作成し, 各科の協力をお願いしているところです. 同時に医師だ けではなく, 病院に勤務する全ての職種の医療人を対象とした継続的な教育の支援も行って参りたいと思います. 
幸いにも本学は, 平成 21 年度の国と都の事業の中で全国 2 カ所に設置された救急医療トレーニングセンターの 一つに認定されました。 また付属病院は，平成 20 年度から大学病院連携型高度医療人養成推進事業として地方大 学からの医療人教育も行っております。付属病院臨床研修センターはこれら国や自治体事業の空口としての機能も 果たしていきたいと思います.

付属病院臨床研修センターは，設立間もない新しい組織でありますが，日本医科大学の学是である「克己殉公」, 教育理念である「愛と研究心を有する質の高い医師と医学者の育成」の実践を支援する拠点として頑張っていきた いと思います，どうかご支援のほど，お願い申しあげます．

(受付 : 2010 年 1 月 12 日)

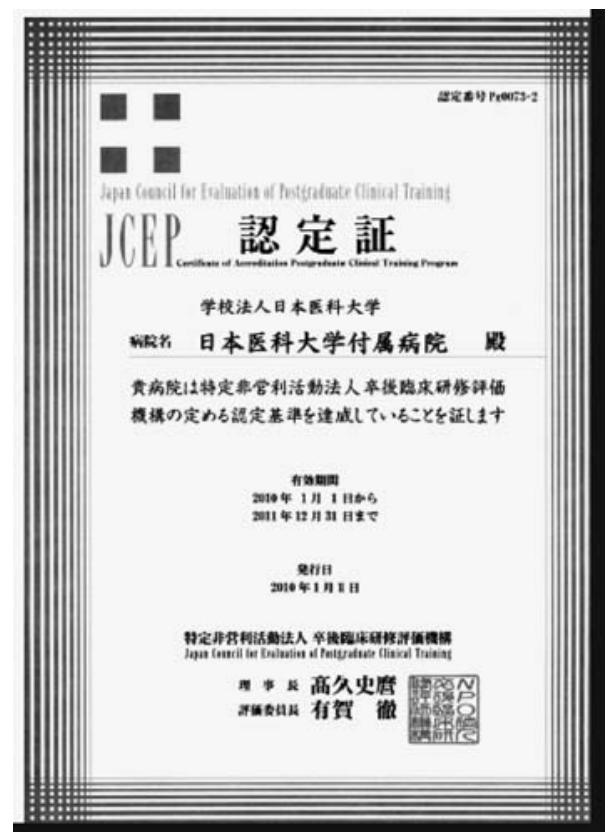

